\title{
Efektivitas Penggunaan Video Pembelajaran dalam Meningkatkan Motivasi dan Hasil Belajar Siswa dalam Pembelajaran Front Office di Kelas Xi Akomodasi Perhotelan SMK N 3 Garut
}

\author{
Irwanto $^{1}$, Wini Guswiani ${ }^{2}$ \\ ${ }^{1}$ Pendidikan Vokasional Teknik Elektro, FKIP, Universitas Sultan Ageng Tirtayasa, \\ Jl. Ciwaru Raya, No. 25 Serang-Banten \\ ${ }^{2}$ Institut Pendidikan Indonesia, Jl. Pahlawan, No. 10 Garut-Jawa Barat \\ E-mail: irwanto.ir@untirta.ac.id
}

\begin{abstract}
Abstrak
Penelitian ini bertujuan untuk mengetahui penggunaan media video terhadap motivasi dan hasil belajar siswa. Pendekatan penelitian yang digunakan adalah pedekatan kuantitatif dengan Metode penelitian Quasi Experimental Design, yaitu desain penelitian eksperimen, dengan tehnik pengumpulan data menggunakan tes dan observasi. Berdasarkan hasil analisis data, diperoleh kesimpulan bahwa penggunaan video pembelajaran sangat efektifuntuk meningkatkan motivasi dan hasil belajar siswa dalam pembelajaran Front Office di Kelas XI Akomodasi Perhotelan SMKN 3 Garut. Hal ini ditunjukan dengan adanya perbedaan antara motivasi dan hasil belajar siswa antara kelas yang menerapkan media video dengan kelas yang diberikan media video pembelajaran.
\end{abstract}

Kata Kunci: video pembelajaran, motivasi, belajar, front office.

\begin{abstract}
This study aims to determine the use of video media on student motivation and learning outcomes. The research approach used is a quantitative approach to the Quasi Experimental Design research method, which is an experimental research design, with data collection techniques using tests and observations. Based on the results of data analysis, it was concluded that the use of instructional videos is very effective in increasing motivation and student learning outcomes in Front Office learning in Class XI Hospitality Accommodation at SMKN 3 Garut. This is indicated by the difference between motivation and student learning outcomes between classes applying video media to classes given learning video media.
\end{abstract}

Keywords: learning videos, motivation, learning, front office

\section{PENDAHULUAN}

Pendidikan merupakan investasi kehidupan manusia dimana kualitas kehidupan manusia dapat diukur salah satunya melalui pendidikan, dan masyarakat yang perduli terhadap pendidikan sudah barang tentu kehidupan serta kesejahteraan masyarakat akan meningkat. Pentingnya pendidikan tercantum dalam Undang Undang
Sistem Pendidikan Nasional No 20 Tahun $2003^{1}$ yang menyebutkan bahwa pendidikan adalah usaha sadar dan terencana untuk mewujudkan suasana belajar dan proses pembelajaran agar

${ }^{1}$ Undang-Undang Nomor 20 Tahun 2003 tentang Sistem Pendidikan Nasional. LamanDepDikNas [online]. Tersedia: http//:www.depdiknas.go.id/uusisdiknas.htm. diakses 2 Juni 2014. hlm. 3. 
peserta didik secara aktif mengembangkan potensi dirinya untuk memiliki kekuatan spiritual keagamaan, pengendalian diri, kepribadian, kecerdasan, akhlak mulia, serta keterampilan yang diperlukan dirinya, masyarakat, bangsa dan negara.

Pengertian pendidikan di atas mengisyaratkan pendidikan perlu perencanaan yang disadari oleh seluruh pihak yang terlibat dalam sistem pendidikan, diantaranya input sistem pendidikan yaitu guru, siswa serta sarana prasarana yang memerlukan persiapan serta koordinasi yang kuat agar sistem tersebut dapat berjalan dengan maksimal. Pendidikan dapat diwujudkan salah satunya dengan adanya lembaga yang bernama sekolah. Sekolah merupakan suatu lembaga pendidikan formal yang mempunyai tanggung jawab untuk terus mendidik siswanya ${ }^{2}$. Untuk itu sekolah menyelenggarakan proses belajar mengajar sebagai realisasi dari tujuan pendidikan yang telah ditetapkanSekolah yang merupakan lembaga formal yang memfasilitasi siswa dalam mendapatkan hak belajar dan kewajiban sekolah adalah menyediakan pendidikan yang sesuai dengan kebutuhan siswa dan tuntutan zaman, seperti variabel yang berpengaruh terhadap sistem keberhasilan pembelajaran adalah : (1) Faktor Guru, (2) Faktor Siswa, (3) Faktor sarana dan prasarana dan (4) Faktor lingkungan ${ }^{3}$.

Dari keempat variabel diatas faktor yang paling penting dalam keberhasilan sistem pembelajaran karena guru yang secara langsung berhadapan dengan siswa baik berperang sebagai perencana (planner) atau desainer (designer) pembelajaran sebagai implementator sehingga dibutuhkan tenaga pengajar yang memiliki kemampuan visioner, selalu memperbaharui informasi serta pengetahuan yang dimilikinya.

Kenyataan dilapangan masih mengindikasikan kurangnya profesionalisme

${ }^{2}$ Wijaya, C. dan Rusyan T.A. 1991. Kemampuan Dasar Guru Dalam Mengajar. Bandung: PT Remaja Rosdakarya. hlm. 27.

${ }^{3}$ Sanjaya, W. (2008). Perencanaan dan Desain sistem Pembelajaran. Jakarta. Kencana Prenada Media Group. hlm 25. serta daya kreatifitas guru dalam mengajar. Programe For Internatoinal Study Assessment (PISA) menepatkan Indonesia sebagai salah satu negara dengan peringkat terendah dalam pencapaian mutu pendidikan. (Tempo 6 Desember 2013), sementara itu data yang dilansir oleh situs okezone, tanggal 1 Juni 2013 menyebutkan bahwa menurut Education For All Global Monitoring Report 2012 oleh UNESCO, pendidikan Indonesia berada diperingkat ke64 untuk pendidikan di seluruh dunia dari 120 negara. Education Development Index (EDI) Indonesia, pada 2011 Indonesia berada diperingkat ke-69 dari 127 negara.

Salah satu masalah dalam dunia pendidikan adalah rendahnya kualitas guru, keadaan guru di Indonesia juga amat memprihatinkan. Kebanyakan guru belum memiliki profesionalisme yang memadai untuk menjalankan tugasnya. SMK (Sekolah Menengah Kejuruan) merupakan salah satu bentuk satuan pendidikan formal yang menyelenggarakan pendidikan kejuruan pada jenjang pendidikan menengah sebagai lanjutan dari SMP, MTs, atau bentuk lain yang sederajat. Sekolah di jenjang pendidikan dan jenis kejuruan dapat bernama Sekolah Menengah Kejuruan (SMK) atau Madrasah Aliyah Kejuruan (MAK), atau bentuk lain yang sederajat (UU Sisdiknas Nomor 20 Tahun 2003). SMK memiliki banyak keahlian yang disesuaikan dengan kebutuhan dunia kerja. Salah satu program keahlian yang terdapat di SMKN 3 Garut adalah program keahlian akomodasi perhotelan.

Siswa dan siswi jurusan akomodasi perhotelan dipersiapkan untuk menjadi tenaga kerja perhotelan yang profesional serta berdaya saing baik sebagai front liner, housekeeper ataupun sebagai tenaga back office di hotel. Siswa serta siswi SMK dipersiapkan menjadi tenaga siap pakai artinya setiap lulusan dari SMK telah dibekali baik secara teoritis juga aplikatif mengenai program keahlian yang diampunya. SMKN 3 Garut program keahlian akomodasi perhotelan dibekali berbagai kompetensi yang menunjang pekerjaannya kelak di bidang perhotelan, sehingga untuk 
menghasilkan siswa-siswi yang berkualitas pengajar dituntut untuk lebih berinovasi dalam merancang kegiatan belajar mengajar agar anak tidak hanya ingat mengenai materi tetapi juga paham seperti pepatah mengatakan "I hear I forget, I see I remember, I do I understand ".

Salah satu seksi yang berada di hotel dan merupakan salah satu kompetensi yang terdapat pada program keahlian akomodasi perhotelan yaitu Front Office. Front Office merupakan bagian depan yang berfungsi melayani tamu (guest) secara langsung baik reservasi, registrasi dan layanan antar barang (bell boy $)^{4}$. Front Office yang terdiri dari aspek grooming (penampilan), attitude (tingkah laku), conversation (percakapan / bahasa) sangatlah penting adanya.

Perwujudan kualitas pendidikan nasional selain di dukung oleh sumber daya manusia yaitu pengajar yang berkualitas serta kompeten haruslah didukung oleh adanya sarana serta prasarana yang "up to date" atau kekinian, dimana masa globalisasi menuntut kita untuk selalu menyesuaikan dengan kemampuan teknologi yang semakin pesat. Maraknya penggunaan teknologi sampai pada bidang pendidikan merupakan tantangan bagi setiap stakeholder pendidikan untuk selalu beradptasi. Lebih khusus lagi penggunaan teknologi pembelajaran yaitu aplikasi teknologi yang digunakan secara lebih spesifik yaitu di lingkungan kelas.

Teknologi pembelajaran adalah media yang lahir sebagai revolusi komunikasi yang dapat digunakan untuk keperluan pembelajaran disamping penggunaan buku teks, OHP, komputer dan yang lainnya. Guru juga harus memiliki kemampuan untuk menyeleksi media pendidikan mana yang dibutuhkan serta sesuai dengan materi pembelajaran agar proses belajar mengajar berlangsung secara aktif, kreatif, serta meningkatkan motivasi belajar siswa yang pasti berpengaruh terhadap hasil belajar

${ }^{4}$ Suwithi, Ni Wayan. 2011. Pengantar Akomodasi Perhotelan Jilid 1. Jakarta: Tidak diperjualbelikan. Hlm. 32. siswa. Keterampilan berbicara merupakan salah satu aspek penting dalam keterampilan percakapan. Keretampilan berbahasa sangatlah penting karena bagian Front Office merupakan center of information atau pusat informasi yang terdapat di hotel sehingga untuk menciptakan pelayanan yang maksimal kepada tamu hotel dibutuhkan kompetensi yang lebih dari cukup dan keterampilan berbicara dengan penggunaan bahasa yang sesuai (polite) perlu dikuasai oleh para front liner.

Bagian tersulit dalam berbicara adalah mengetahui apa yang akan dibicarakan dan bagaimana memulainya. Oleh karena itu diperlukan sebuah media yang dapat membantu dalam pembelajaran keterampilan berbicara, terutama dalam penggunaan bahasa yang baik dan benar. Kemampuan berbahasa harus dilatih baik secara verbal ataupun dengan menggunakan media sebagai contoh, sehingga anak tidak hanya belajar secara audio tetapi melibatkan pula visualnya, sehingga penggunaan media sangat dibutuhkan untuk memperjelas pesan yang ingin disampaikan, melihat gesture (gerak tubuh), media dapat meningkatkan motivasi dalam belajar serta membuat pembelajaran lebih bervariasi dan diharapkan agar pembelajaran yang dilakukan anak lebih bermakna. Dari beberapa penelitian tentang media yang digunakan dalam pembelajaran, disimpulkan bahwa media dapat mendukung tercapainya tujuan pembelajaran karena para siswa dapat lebih mudah memahami materi yang disampaikan. Adapun media yang dijadikan sarana untuk menunjang efektivitas dalam pembelajaran berbicara dalam penelitian ini adalah media video.

Melalui media video kemampuan siswa untuk menyerap informasi lebih tersampaikan melalui tayang visual atau film serta dilaksanakan praktek daripada mendengan informasi secara verbal, hal tersebut terbukti dari nilai yang diperoleh siswa XI akomodasi Perhotelan pada pembelajaran Front Office dengan melalui metode yang masih bersifat konvensional serta penggunaan media yang kurang variatif hal tersebut berpengaruh terhadap motivasi belajar 
siswa yang rendah hal tersebut dapat terindikasi dari sikap siswa pada saat belajar terlihat tidak semangat dan kurang fokus (banyak menguap, mengobrol dengan teman, bermain gadget), kurang perhatian terhadap materi yang disampaikan dan hal tersebut berpengaruh terhadap hasil pembelajaran. Hasil belajar yang masih kurang dari Kriteria Ketuntasan Minimal (KKM).

Berdasarkan pengamatan sementara di Kelas XI akomodasi perhotelan ditemukan masalah mengenai kurangnya motivasi belajar sehingga berakibat pada hasil belajar siswa. Berdasarkan uraian masalah di atas, maka Peneliti tertarik untuk mendalami serta menganalisis pengembangan kompetensi khususnya di Sekolah menengah Kejuruan yang dituangkan dalam sebuah karya ilmiah yang berjudul "Efektivitas Penggunaan Video Pembelajaran Dalam Meningkatkan Motivasi Dan Hasil Belajar Siswa Dalam Pembelajaran Front Office Di Kelas XI Akomodasi Perhotelan SMKN 3 Garut".

\section{METODE PENELITIAN}

Metode penelitian dengan menggunakan bentuk Quasi Experimental Design, yaitu desain penelitian eksperimen, yang merupakan pengembangan dari true experimental design, melalui Nonequivalent Control Group Design. Quasi eksperimental ini merupakan desain penelitian yang terdapat pengontrolan terhadap kelompok pengontrol atau pembanding, adanya tes awal sebelum diberi perlakuan dan tes akhir setelah diberi perlakuan pada kelompok eksperimen ${ }^{5}$.

Terdapat dua kelompok yang dipilih yaitu kelompok eksperimen dan kelompok kontrol. Keduanya memperoleh pretest dan posttest. Perbedaan hasil pada kelompok eksperimen dan kelompok kontrol dapat menunjukkan adanya pengaruh atau tidaknya penggunaan media video dalam pembelajaran yang diberikan kepada kelas eksperimen. Desain penelitian yang dilakukan dengan bentuk

${ }^{5}$ Sugiyono. 2009. Statistik Nonparametris untuk penelitian. Bandung: Alfabeta. hlm. 23.
Quasi Experimental Design ini dikhususkan kepada bentuk "Non Equivalent Control Group Design“. Dalam desain ini terdapat pretest, sebelum dilakukan perlakuan sama seperti pada bentuk pretest-posttest control group design di true experimental design, hanya pada desain ini kelompok eksperimen dan maupun kelompok kontrol tidak dipilih secara random atau acak. Dengan menggunakan metode penelitian bentuk Quasi Experimental Design perlakuan kepada sampel tergambar pada Tabel 1 di bawah ini:

Tabel 1. Rancangan Eksperimen

\begin{tabular}{ccc}
\hline $\mathbf{O}_{1}$ & $\mathrm{X}$ & $\mathbf{O}_{2}$ \\
$\mathbf{O}_{3}$ & - & $\mathbf{O}_{4}$ \\
\hline
\end{tabular}

Keterangan:

$\mathrm{O}_{1}=$ Pretest pada kelas eksperimen

$\mathrm{O}_{2}=$ Posttest pada kelas eksperimen

$\mathrm{O}_{3}=$ Pretest pada kelas kontrol

$\mathrm{O}_{4}=$ Posttest pada kelas kontrol

$\mathrm{X}=$ Perlakuan (Treatment)

Efektivitas penggunaan media video pembelajaran terhadap motivasi dan hasil belajar adalah $\mathrm{O}_{2}-\mathrm{O}_{1}$.

\section{HASIL DAN PEMBAHASAN \\ Hasil Penelitian}

Efektivitas penggunaan video pembelajaran terhadap peningkatan motivasi siswa dalam pembelajaran Front Office di Kelas XI Akomodasi Perhotelan SMKN 3 Garut

Hasil observasi dan pembagian instrument penelitian berupa angket motivasi belajar kepada siswa yang tidak menggunakan video pembelajaran yaitu di kelas XI AP1 (kelas kontrol). Tampak rata-rata nilai motivasi belajar pada kelompok siswa yang pembelajarannya tanpa menggunakan video pembelajaran adalah sebesar 57,07. Sementara hasil observasi dan pembagian instrument penelitian berupa angket motivasi belajar kepada siswa yang menggunakan video pembelajaran yaitu kelas XI AP 2 (kelas eksperimen).

Tampak rata-rata nilai motivasi belajar pada kelompok siswa yang pembelajarannya 
menggunakan video pembelajaran adalah sebesar 60,34. Dari hasil perbandingan dengan hasil menunjukkan nilai yang signifikan antara motivasi kelas kontrol dan motivasi kelas eksperimen. Pada kelas kontrol menunjukkan motivasi belajar dengan rata-rata 57,07 sementara pada kelas eksperimen menunjukkan rata-rata 60,34 , dari hasil tersebut dapat disimpulan bahwa penggunaan media video pembelajaran efektif dalam meningkatkan motivasi belajar siswa dalam pembelajaran front office.

Efektivitas penggunaan video pembelajaran terhadap peningkatan hasil belajar siswa dalam pembelajaran Front Office di Kelas XI Akomodasi Perhotelan SMKN 3 Garut

Hasil belajar siswa yang tidak menggunakan video pembelajaran yaitu kelas XI AP 1 (kelas kontrol). Tampak rata-rata nilai hasil belajar siswa yang tidak menggunakan video pembelajaran yaitu nilai pretest sebesar 39,83 sedangkan pada saat post test sebesar 51,33. Sementara, hasil belajar siswa yang menggunakan video pembelajaran yaitu kelas XI AP 2 (kelas eksperimen). Tampak rata-rata nilai hasil belajar siswa yang menggunakan video pembelajaran untuk nilai pretest sebesar 45,34 sedangkan pada saat posttest sebesar 63, 28.

\section{Perbedaan efektivitas penggunaan video pembelajaran terhadap peningkatan motivasi dan hasil belajar siswa dalam Front Office di Kelas XI Akomodasi Perhotelan SMKN 3 Garut}

Efektivitas dapat dilihat dari ada atau tidaknya perubahan setelah diberikan perlakuan. Berikut gambaran hasil belajar dan motivasi pada kelompok kontrol dan eksperimen. Berdasarkan hasil perhitungan, terlihat bahwa terdapat nilai yang menunjukkan keefektifan penggunaan video pembelajaran terhadap peningkatan motivasi juga kenaikan hasil belajar dari sebelum dilakukan pembelajaran pada kedua kelompok. Untuk variabel motivasi belajar di kelas kontrol hanya mendapatkan nilai sebesar 57,07 sementara pada kelas eksperimen yaitu sebesar 60,34 , terdapat perbedaan nilai yang signifikan. Pada kelompok eksperimen, rata-rata hasil belajar sebelum dilakukan pembelajaran dengan video sebesar 45,34 sedangkan setelah perlakuan, didapat rata-rata skor sebesar 63,28. Untuk kelompok kontrol pun mengalami kenaikan skor hasil belajar, hanya kenaikannya tidak sebesar pada kelompok eksperimen.

Untuk menguji efektivitas penggunaan video pembelajaran dilakukan dengan uji beda 2 kelompok. Sebelum melakukan pengujian, data terlebih dahulu diuji normalitas dan homogenitasnya. Secara lebih detail akan dijelaskan pada penjelasan selanjutnya. Pengujian normalitas data digunakan uji Kolmogorov-Smirnov. Kriteria pengujian yaitu tolak Ho jika p-value (asymp.sig) < 0,05 . Pada hasil pengujian normalitas diatas dengan menggunakan Kolmogorov-Smirnov test hasil belajar dan motivasi baik sebelum dan setelah dilakukan memiliki p-value (asymp. sig) yang lebih besar dari nilai signifikansi $\alpha$ $(0,05)$. Dengan demikian, hasil pretest kelas eksperimen dan kelas kontrol pada efektitifitas penggunaan video pembelajaran berdistribusi normal. Hasil postest kelas eksperimen dan kelas kontrol berdistribusi normal. Untuk selanjutnya dilakukan uji homogenitas pada kedua kelas tersebut.

Kriteria pengujian yaitu tolak Ho jika $\mathrm{F}$ hitung $>\mathrm{F}$ tabel. Pada hasil pengujian homogenitas diatas dengan menggunakan uji $\mathrm{F}$, data hasil belajar sebelum dan setelah dilakukan memiliki $\mathrm{F}$ hitung $(1,41)$ yang lebih kecil $\mathrm{F}$ tabel $(1,88)$ sehingga Ho diterima. Dengan demikian dapat disimpulkan bahwa data hasil belajar pada kedua kelompok homogen. Hasil yang berbeda ditunjukkan oleh data hasil observasi. Hasil observasi motivasi memiliki F hitung $(2,44)$ yang lebih besar F tabel $(1,88)$ sehingga Ho ditolak . Dengan demikian dapat disimpulkan bahwa data hasil observasi pada kedua kelompok tidak homogen.

Uji beda independen digunakan untuk menguji efektivitas penggunaan video 
pembelajaran. Berikut adalah hasil pengujian dengan menggunakan bantuan SPSS. Untuk menguji adanya peningkatan hasil belajar dilakukan uji beda dengan uji t. Pengujian dinyatakan signifikan (menolak Ho) jika $\mathrm{p}$-value $<\alpha(0,05)$. Pengujian menggunakan data selisih, untuk melihat apakah terdapat perbedaan hasil belajar sebelum dan setelah dilakukan pembelajaran dengan video. Terlihat bahwa hasil perhitungan didapat $\mathrm{p}$-value sebesar 0,00 (lebih kecil dari 0,05) maka $\mathrm{H}_{0}$ ditolak. Ini menunjukkan, hasil belajar pada kelompok kontrol maupun eksperimen memiliki perbedaan. Ini ditunjukkan dengan skor ratarata selisih hasil belajar sebelum dengan setelah dilakukannya pembelajaran dengan video pada kelompok eksperimen memiliki peningkatan sebesar 17,93\% , yang lebih besar dibandingkan dengan kelompok kontrol 11,50\%. Hasil yang berbeda ditunjukkan oleh hasil observasi pada kedua kelompok. Terlihat bahwa hasil perhitungan didapat $p$-value sebesar 0,072 (lebih besar dari 0,05) maka $\mathrm{H}_{0}$ diterima. Ini menunjukkan, motivasi pada kelompok kontrol maupun eksperimen memiliki persamaan. Ini ditunjukkan dengan skor motivasi pada kelompok eksperimen sebesar 60,34\%, tidak jauh berbeda dengan kelompok kontrol $(57,07 \%)$.

\section{PEMBAHASAN}

Efektivitas penggunaan video pembelajaran terhadap peningkatan motivasi siswa dalam pembelajaran Front Office di Kelas XI Akomodasi Perhotelan SMKN 3 Garut

Hasil analisis data menunjukkan penggunaan video pembelajaran efektif untuk meningkatkan motivasi belajar siswa dalam pembelajaran Front Office dengan 20 item pertanyaan yang ditunjukan oleh hasil kelas eksperimen yaitu memiliki nilai 60,34 sedangkan pada kelas kontrol memperoleh nilai sebesar 57,07. Hal tersebut menunjukkan bahwa penggunaan video pembelajaran efektif digunakan untuk meningkatkan motivasi belajar siswa.
Hal ini sesuai dengan pendapat ${ }^{6}$ yang menyatakan bahwa adanya prinsip pemacu akan mendorong siswa untuk melakukan berbagai tindakan. Pemacu dalam penelitian ini adalah dengan digunakannya video pembelajaran yang dapat meningkatkan motivasi belajar siswa yang timbul dari dorongan siswa unruk melakukan tindakan dan untuk melakukan sesuatu sebaik mungkin. Proses pengajaran yang efektif dapat terbentuk melalui pengajaran yang memiliki ciri-ciri dalam proses dalam proses pembelajarannya, yakni metode mengajar yang digunakan hendaknya sedemikian rupa bervariasi sesuai dengan tujuan dan bahan yang diajarkan yang dalam penelitian ini adalah menggunakan video pembelajaran. Dengan metode mengajar yang bervariasi akan membuat siswa lebih senang dan bersemangat dalam belajar, sehingga dapat memberikan hasil pembelajaran yang lebih baik.

Terkait dengan pembelajaran, motivasi berfungsi untuk membantu siswa memperoleh hasil belajar yang baik. Makin tepat motivasi yang diberikan oleh guru atau didapatkan oleh siswa, makin berhasil pula siswa mempelajari suatu pelajaran, karena motivasi akan menentukan intensitas usaha belajar bagi para siswa, yang pada akhirny makin mempercepat usaha pencapaian tujuan yang diinginkan. Artinya, makin baik motivasi belajar yang diberikan guru, maka makin baik pula aktivitas dan intensitas belajar siswa, sehingga diharapkan mampu meningkatkan hasil belajarnya.

Motivasi belajar yang dimiliki, baik internal maupun eksternal merupakan salah satu fakor yang dapat mempengaruhi pencapaian hasil belajar siswa. Meskipun ddemikian, motivasi ini dapat berubah atau hilang seketika, bahkan muncul secara tiba-tiba. Hal ini terjadi karena adanya faktor-faktor yang mempengaruhi motivasi belajar, yaitu cita-cita atau aspirasi siswa, kemampuan siswa, kondisi siswa, kondisi jasmani dan rohani, lingkungan, unsur-

${ }^{6}$ Surya, Mohamad. (20040. Psikologi Pembelajaran dan Pengajaran. Bandung: Pusaka Bani Quraisy. hlm. 34. 
unsur dalam belajar dan upaya guru dalam membelajarkan siswa.

Penggunaan video pembelajaran efektif untuk meningkatkan motivasi belajar siswa. Hasil penelitian di lapangan tersebut didukung dengan hasil penelitian lain yang tercatat dalam sebuah jurnal dengan judul "Pengaruh Penggunaan Media Video Terhadap Motivasi Dan Hasil Belajar Siswa pada Mata Pelajaran Ilmu Pengetahuan Sosial Di Sekolah Menengah Pertama Negeri 2 Lais Musi Banyu Asin", pada hasil penelitian di jurnal tersebut menyebutkan hasil yang serupa yaitu penggunaan media video berpengaruh signifikan dan efektiv terhadap peningkatan motivasi belajar siswa sekaligus hasil belajar siswa Sekolah menengah Pertama.

Belajar yang efektif dapat membantu siswa untuk meningkatkan kemampuan yang diharapkan sesuai dengan tujuan yang ingin disampaikan ${ }^{7}$. Untuk meningkatkan cara belajar yang efektif perlu memperhatikan beberapa hal berikut:

1. Kondisi internal

Yaitu situasi yang ada di dalam diri siswa itu sendiri, mislanya ksehatan, keamanan, ketentraman dan sebagainya. Siswa dapat belajar dengan baik apabila kebutuhankebutuhannya tersebut terpenuhi.

2. Kondisi eksternal

Yaitu kondisi yang ada diluar diri pribadi manusia, seperti keadaan rumah (baik lingkungan, kebersihan dan penerangannya), serta keadaan lingkungan fisik yang lain. Untuk dapat belajar yang efektif diperlukan lingkungan fisik yang baik dan teratur.

3. Strategi belajar

Belajar yang efisien dapat tercapai apabila dapat menggunakan strategi belajar yang tepat. Strategi belajar diperlukan untuk dapat mencapai hasil yang semaksimal mungkin.

Motivasi adalah perubahan energy dalam diri seseorang yang ditandai dengan

${ }^{7}$ Slameto. 2010. Belajar dan Faktor-faktor yang mempengaruhinya. Jakarta: Rineka Cipta. hlm. 23. munculnya "feeling" dan didahului dengan tanggapan terhadap adanya tujuan ${ }^{8}$. Motivasi menyebabkan perubahan energi yang ada pada diri manusia. Dalam kegiatan belajar, motivasi diartikan sebagai keseluruhan daya penggerak di dalam diri siswa yang menimbulkan kegiatan belajar. Siswa memiliki yang memiliki motivasi yang kuat akan mempunyai banyak energi untuk melakukan kegiatan belajar. Keberhasilan belajar siswa ditentukan oleh motivasi belajar yang dimiliki oleh siswa. Siswa akan memiliki hasil belajar yang tinggi jika ia memiliki motivasi yang tinggi dan sebaliknya siswa yang memiliki motivasi yang rendah akan menurunkan hasil belajarnya pula.

Motivasi memiliki manfaat yang besar sebagai pendorong yang kuat dalam mencapai hasil belajar yang baik. Sehingga siswa yang mempunyai motivasi yang tinggi akan berkonsetrasi dalam belajaranya. Konsentrasi yng terbentuk akan mempermudah siswa memahami materi yang dipelajari. Bila siswa menyadari bahwa belajar merupakan suatu alat untuk mencapai tujuan yang dianggap penting, dan bila siswa melihat bahwa hasil dari pengalaman belajar akan membawa kemajuan pada dirinya, ia akan lebih berminat untuk mempelajarinya.

\section{Efektivitas penggunaan video pembelajaran terhadap peningkatan hasil belajar siswa dalam pembelajaran Front Office di Kelas XI Akomodasi Perhotelan SMKN 3 Garut}

Hasil analisis data menunjukkan hasil rata-rata pretest dan posttest pada kelas kontrol dan pada kelas eksperimen menunjukkan bahwa penggunaan video pembeajaran sangat efektif dalam meningkatkan hasil belajar siswa yang terbukti dari rata-rata hasil pretest dan posttest. Dari hasil perhitungan sebelumnya dapat ditarik benang merah yang berarti penggunaan video pembelajaran efektif untuk meningkatkan hasil belajar siswa karena terdapat perbedaan hasil belajar dari kelas kontrol yaitu dengan selisih

${ }^{8}$ Sardiman. 2010. Interaksi dan Motivasi Belajar Mengajar. Jakarta: PT Raja Grafindo Persada. hlm. 12. 
pretest posttest 11,50 sedangkan pada kelas eksperimen sebesar 17,93. Dari hasil tersebut sejalan dengan pendapat ${ }^{9}$ yang menyatakan bahwa perubahan perilaku peserta didik sebagai hasil belajar dapat diamati dan diukur dalam bentuk perubahan pengetahuan, sikap, dan keterampilan yang secara eksplisit ditujukan dengan besarnya symbol/angka yang didapat peserta didik pada saat penilaian dan pengukuran (evaluasi atau asesmen) dilakukan.

Hasil belajar biasanya dinyatakan atau diukur dengan nilai akademik peserta didik dalam mata pelajaran yang diikutinya. Baik buruknya prestasi belajar tersebut tergantung pada ukuran baku yang digunakan dalam sistem penilaian yang berlaku. Hasil belajar tampak sebagai perubahan perilaku siswa yang dapat diamati dan diukur.

Faktor-faktor yang dapat mempengaruhi prestasi siswa antara lain adalah faktor penggunaan media pembelajaran, siswa akan merasa jenuh dalam mengikuti kegiatan pembelajaran jika media yang dipakai oleh guru tidak pernah berubah. Siswa akan termotivasi menambah pengetahuan jika guru dapat menggunakan media pembelajaran yang lebih memudahkan siswa dalam menyerap materi.

Media pembelajaran yang dapat diguanakan adalah media video pembelajaran. Ada banyak kelebihan video ketika digunakan sebagai media pembelajaran di antaranya video merupakan media yang cocok untuk pelbagai ilmu pembelajaran, seperti kelas, kelompok kecil, bahkan satu siswa seorang diri sekalipun. Hal itu, tidak dapat dilepaskan dari kondisi para siswa saat ini yang tumbuh berkembang dalam dekapan budaya televisi, di mana paling tidak setiap 30 menit menayangkan program yang berbeda ${ }^{10}$. Dari itu, video dengan

${ }^{9}$ Syam, Islamudin. 2015. Teori hasil belajar menurut para ahli. Tersedia: http://www.slideshare.net/ ismdn/teori-hasil-belajar-menurut-para-ahli diakses 10 Juni 2014 pukul 13.00.

${ }^{10}$ Sutanto. 2011. Menerima dan memproses Reservasi. Bandung: Alfabeta. hlm. 23. durasi yang hanya beberapa menit mampu memberikan keluwesan lebih bagi guru dan dapat mengarahkan pembelajaran secara langsung pada kebutuhan siswa. Kebutuhan siswa yang ada tidak lepas dari adanya tujuan pembelajaran yang jelas dan terarah. Dalam pencapaian tujuan pembelajaran, banyak faktor yang dapat mempengaruhi tercapianya tujuan-tujuan tersebut. Faktor-faktor yang mempengaruhi satu dengan yang lainnya saling berkaitan, sehingga apabila faktor yang satu terabaikan maka hasil belajar itu sendiri menjadi tidak optimal. Faktor yang mempengaruhi hasil belajar yaitu faktor guru, faktor siswa, sarana dan prasarana dan faktor lingkungan. Dari keempat faktor tersebut, tentunya masing masing meiliki peran yang sangat penting dan saling terintegrasi antara faktor satu dengan faktor yang lainnya ${ }^{11}$.

Penggunaan video pembelajaran pun berkaitan dengan faktor guru, siswa, sarana prasarana dan faktor lingkungan. Salah satu kendala yang mungkin terjadi di lapangan yaitu ketersediaan sarana dan prasarana. Karena, bila sarana dan prasarana tidak medukung untuk penggunaan video pembelajaran, maka salah satu faktor penunjang keberhasilan pembelajaran yang berhubungan dengan teknologi sulit untuk dicapai. Sehingga dapat dikatakan bahwa antara siswa dengan faktor lain yang dapat mendukung proses pembelajaran yang diharapkan oleh semua pihak ${ }^{12}$.

Guru, orang tua siswa atau bahkan siswa yang bersangkutan selalu ingin mencapai hasil belajar yang maksimal dala proses pembelajaran. Siswa harus selalu mendapatkan dorongan semangat untuk selalu antusias dan nyaman dalam proses pembelajaran ${ }^{13}$. Faktor guru dan orang tua merupakan faktor penting yang berperan sebagai penentudalam

${ }^{11}$ Sukmadinata, N. S. 2007. Landasan Psikologi Proses Pembelajaran. Bandung: Rosdakarya. hlm. 14.

${ }^{12}$ Sudjana, N. 2009. Dasar-Dasar Proses Belajar Mengajar. Bandung: Sinar Baru Algesindo. hlm. 34.

${ }^{13}$ Syah, M. 2001. Psikologi Pendidikan dengan Pendekatan Baru. Bandung: PT. Remaja Rosdakarya. hlm. 37. 
terciptanya semangat dan kenyamanan siswa dalam proses belajar ${ }^{14}$. Karena dengan dukungan guru dan orang tua, siswa akan lebih fokus dalam mencapai tujuan yang ingin mereka capai. Setiap masalah yang dialami siswaakn terselesainkan dengan adanya komunikasi yag baik dengan guru dan orang tua ${ }^{15}$.

Bila setiap masalah tidak terselesaikan dengan adanya komunikasi yang baik, maka masah-masalah lain yang muncul terakumulasi dan menumpuk. Dengan banyaknya masalah yang dihadapi, dikhawatirkan fokus, antusiasme, minat serta motivasi belajar siswa semakin lama semakin berkurang dan akan menjadi faktor yang akan sangat menghambat terhadap keberhasilan siswa dalam proses pembelajaran. Tidak ada seorang pun yang menginginkan hasil yang buruk dalam segala hal. Demikian hal nya dengan siswa, mereka pasti ingin mencapai hasil terbaik dalam proses pembelajaran yang mereka jalani. Setiap usaha yang dilakukan oleh siswa akan menghasilkan dampak yang berbeda satu sama lain. Walaupun peran guru dapat diakatan maksimal, tetapi bila faktor dari luar lingkungan pendidikan kurang mendukung siswa dalam memperoleh hasil belajar siswa yang maksimal, maka dikhawatirkan keinginan siswa untuk memperoleh hasil terbaik pun akan mengalami hambatan ${ }^{16}$.

\section{Perbedaan efektivitas penggunaan video pembelajaran terhadap peningkatan motivasi dan hasil belajar siswa dalam Front Office di Kelas XI Akomodasi Perhotelan SMKN 3 Garut}

Perkembangan teknologi yang semakin pesat sangat berpengaruh pada kegiatan belajar di sekolah. Wujud nyata produk teknologi

\footnotetext{
${ }^{14}$ Surya, Mohamad. (20040. Psikologi Pembelajaran dan Pengajaran. Bandung: Pusaka Bani Quraisy. Hhm. 26

${ }^{15}$ Sardiman. 2010. Interaksi dan Motivasi Belajar Mengajar. Jakarta: PT Raja Grafindo Persada.

${ }^{16}$ Uno, H. 2006. Indikator Motivasi Belajar. Tersedia: http://pendidikanekonomi.com/2013/08/jenisfungsi-dan-indikator-motivasi.html. Diakses: 3 Oktober 2019.
}

yaitu dengan bermunculannya media-media yang menjadi modal dasar dalam penerapan media pembelajaran. Semakin canggih dan lengkap fasilitas yang dapat dimanfaatkan dari sebuah media, maka hal tersebut dapat menjadi perhatian dan daya tarik tersendiri bagi yang mempelajarinya ${ }^{17}$.

Media merupakan alat bantu dalam proses pembelajaran. Dengan berkembangnya teknologi khususnya dalam dunia pendidikan, informasi yang dapat diakses menjadi semakin luas $^{18}$. Informasi dalam bentuk teks, gambar, suara, animasi, video dapat digunakan sebagai media pembelajaran. Penyajian material yang menggabungkan seluruh elemen tersebut menjadikan informasi dapat diterima oleh indra penglihatan dan pendengaran yang menjadi representasi dari kenyataan yang sebenarnya ${ }^{19}$. Media yang digunakan pada penelitian ini adalah video pembelajaran ${ }^{20}$. Video pembelajaran merupakan tayangan yang didesain, dilaksanakan dan dievaluasi secara sistematisuntuk membuat peserta didik belajar sehingga mereka dapat mencapai tujuan pembelajaran secara efektif dan efisien ${ }^{21}$. Dengan menggunakan video pembelajaran, diharapkan pemecahan masalah dalam pembelajaran dapat terselesaikan ${ }^{22}$. Karakteristik multimedia yang mampu meningkatkan motivasi belajar dan hasil belajar siswa yaitu: (a) memiliki lebih dari satu media yang konvergen, misalnnya menggabungkan unsur audio dan visual. (b)

\footnotetext{
${ }^{17}$ Slameto. 2010. Belajar dan Faktor-faktor yang mempengaruhinya. Jakarta: Rineka Cipta. hlm. 29.

${ }^{18}$ Listianing. 2015. Hotel Front Office. Tersedia: http://jenglis.blog.com/hotel-front-office/. Diakses 25 Juni 2019 pukul 15.00 .

19 Usman, U. 1999. Menjadi Guru Profesional. Bandung: PT Remaja Rosdakarya. hlm. 30.

20 Sugiarto, E. 2003. Hotel front Office Administration (Administrasi Kantor Depan Hotel). Jakarta: Gramedia Pusaka Utama. hlm. 28.

21 Suwithi, N. W. 2011 . Pengantar Akomodasi Perhotelan Jilid 1. Jakarta: Tidak diperjualbelikan. Hlm. 28.

22 Suminarsih, I. 2013. Pengaruh penggunaan media video pembelajaran terhadap peningkatan motivasi belajar dan keterampilan berbicara. Garut: Tidak diperjualbelikan. hlm. 28
} 
bersifat interaktif, dalam pengertian memiliki kemampuan untuk mengakomodasi respon pengguna. (c) bersifat mandiri, dalam pengertian member kemudahan dan kelengkapan isi sedemikian rupa sehingga pengguna dapat menggunakan tanpa bimbingan orang lain ${ }^{23}$.

Penggunaan video pembelajaran diharapkan dapat membantu memberikan kesan yang benar, konsep yang tepat, dengan demikian hal yang dilihat atau suara yang didengar dari penggunaan video pembelajaran ini bermanfaat atau berguna bagi siswa. Dengan melihat dan mendengar dapat memberikan kesan dan dapat membuat siswa dapat mengingat setiap detail yang dilihat atau di dengar nya. Harapannya agar materi pelajaran yang disampaikan lebih mudah untuk diingat dan diimplementasikan juga dipraktikan oleh siswa serta kegiatan pembelajaran yang dilaksanakan lebih menarik dan memberikan iklim pembelajaran yang berbeda dari biasanya ${ }^{24}$.

Penggunaan video pembelajaran dapat menghemat waktu dalam penyampaian materi. Karena jarang mengulangi pengcapan yang tidak perlu. Salah satu manfaat penggunaan video pembelajaran adalah membuat ingatan siswa terhadap pelajaran menjadi semakin kuat. Karena dengan menggunakan video pembelajaran siswa mendapatkan suasana belajar di luar kebiasaan mereka sehari-hariyang seringkali mendapatkan pembelajaran secara konvensional.

Pengaplikasian video pembelajaran bertujuan untuk menyajikan informasi baru dengan hal yang menarik. Selain itu, penggunaan video pembelajaran pun dapat memaparkan proses, menjelaskan konsepkonsep yang rumit, mengajakan keterampilan

23 Jaenudin, R. 2015. Pengaruh Penggunaan Media Video Terhadap Motivasi Dan Hasil Belajar Siswapada Mata Pelajaran Ilmu Pengetahuan Social Di Sekolah Menengah Pertama Negeri 2 Lais Musi Banyu Asin. Tersedia: http://www.distrodoc.com/279312pengaruh -penggunaan -media -video -terhadap -motivasi -dan hasil -belajar. Diakses 3 November 2018 pukul 00.30 .

${ }^{24}$ Sulastiyono, A. 2011 . Manajemen Penyelenggaraan Hotel. Bandung: Alfabeta. hlm 43. menyingkat atau memperpanjang waktu dan mempengaruhi sikap siswa selama proses pembelajaran ${ }^{25}$. Lebih dari itu, manfaat dan karakteristik lain dari media video atau film dalam meningkatkan efektivitas dan efesiensi proses pembelajaran, di antaranya adalah $^{26}$ : (a) mengatasi jarak dan waktu, (b) Mampu menggambarkan peristiwaperistiwa masa lalu secara realistis dalam waktu yang singkat, (c) dapat membawa siswa berpetualang dari negara satu ke negara lainnya, dan dari masa yang satu ke masa yang lain, (d) dapat diulang-ulang bila perlu untuk menambah kejelasan, (e) pesan yang disampaikannya cepat dan mudah diingat, (f) megembangkan pikiran dan pendapat para siswa, (g) mengembangkan imajinasi, (h) memperjelas hal-hal yang abstrak dan memberikan penjelasan yang lebih realistic, (i) mampu berperan sebagai media utama untuk mendokumentasikan realitas sosial yang akan dibedah di dalam kelas dan (j) mampu berperan sebagai storyteller yang dapat memancing kreativitas peserta didik dalam mengekspresikan gagasannya ${ }^{27}$.

Selain kelebihan, video/film juga memiliki kekurangan, di antaranya ${ }^{28}$ : sebagaimana media audio-visual yang lain, video juga terlalu menekankan pentingnya materi ketimbang proses pengembangan materi tersebut; pemanfaatan media ini juga terkesan memakan biaya tidak murah, terutama bagi guru, dan

${ }^{25}$ Adriyanto. 2011. Prinsip Pendidikan Vokasi. Tersedia: http://1ptk.blogspot.com/2011/11/prinsippendidikan-vokasional-dari.html. diakses 12 Maret 2015 pukul 15.33 .

${ }^{26}$ Witte, J. P. 2007. Why The Tail The Dogs: The Pernicious Influence Of Product-Oriented Discourse On The Provision Of Educational Technology Suport. Journal of instructional Technology. 27, 203-215.

${ }^{27}$ Saadah, A. R. 2014. Penggunaan CD Interaktif Model Tutorial Untuk Meningkatkan Motivasi Dan Prestasi Belajar Ilmu Pengetahuan Social Siswa Di Kelas V Sekolah Dasar Negeri Haurpanggung III Kecamatan Tarogong Kidul Kabupaten Garut. Garut: Tidak diperjualbelikan.

${ }^{28}$ Sanjaya, W. 2008. Perencanaan dan Desain sistem Pembelajaran. Jakarta. Kencana Prenada Media Group. hlm. 34. 
penanyangannya juga terkait peralatan lainnya seperi videoplayer, layar bagi kelas besar beserta LCD nya, dan lain-lain ${ }^{29}$.

Berdasarkan analisis data penelitian, penggunaan video mempunyai kontribusi yang baik untuk meningkatkan mtivasi dan hasil belajar siswa dalam pembelajaran Front Office. Keberhasilan siswa dalam hasil belajar mengacu pada motivasi yang ditimbulkan oleh situasi pembelajaran dan gaya belajar yang digunakan guru dalam proses pembelajaran ${ }^{30}$.

Secara kuantitatif, penguasaan terhadap materi dapat diukur sebagai hasil belajar ${ }^{31}$. Penilaiannya mencangkup penilaian hasil belajar yang menyangkut aspek ranah kognitif, afektif dan psikomotork tergantung pada pendekatan pembelajaran yang digunakan. Dilihat dari aspek kognitif, kemampuan rendahnya hasil belajar ditentukan oleh rendahnya kemampuan dalam hal: (1) mengingat, (2) memahami, (3) menerapkan, (4) menganalisis, (5) mengevaluasi, (6) menemukan. Selanjutnya siswa akan menemukan kesulitan dalam: (1) menentukan pengetahuan yang relevan dari pengetahuan yang dipelajari di masa lalu, (2) membangun makna dari berbagai hal baik lisan, tertulis maupun bentuk grafik, (3) menggunakan hal yang sama pada satuan yang berbeda, (4) memisahkan sebuah konsep pada masing-masing bagian dan memahami hubungan antar setiap sub bagian, (5) membuat penilaian berdasarkan niali dan standar tertentu, (6) mengatakan sesuatu bagian dari fungsi keseluruhannya dan mengubah setiap elemen menjadi sebuah pola atau struktur yang baru ${ }^{32}$.

\footnotetext{
${ }^{29}$ Smaldino, S. E, dkk. 2008. Instructional technology and Media For learning. Ohio: Pearson Merril prentice Hall.

${ }^{30}$ Wijaya, C. \& Rusyan T. A. 1991. Kemampuan Dasar Guru Dalam Mengajar. Bandung: PT Remaja Rosdakarya. hlm. 45.

${ }^{31}$ Syam, I. 2015. Teori hasil belajar menurut para ahli. Tersedia: http://www.slideshare.net/ismdn/teorihasil-belajar-menurut-para-ahli diakses 10 Juni 2014 pukul 13.00 .

${ }^{32}$ Sudijono, A. 2003. Pengantar Evaluasi Pendidikan. Jakarta: Raja Grafindo. hlm. 28.
}

Pada penelitian ini, peneliti mencoba mengintegrasikan video ke dalam pembelajaran. Diharapkan dengan menggunaakn video pembeajaran, dapat menjadi salah satu langkah maju menjadikan siswa mencapai hasil belajar yang maksimal ${ }^{33}$. Dari hasil penelitian tampak hasil belajar siswa menunjukkan adanya peingkatan terutama pada siswa di kelas eksperimen atau kelas yang mendapatkan perlakuan dengan menggunakan video dengan hasil belajar ke kualifikasi yang lebih tinggi ${ }^{34}$.

Salah satu faktor yang dapat meningkatkan hasil belajar siswa yang diberi perlakuan menggunakan video pembelajaranadalah karena peneliti memiliki asumsi bahwa dengan menggunakan video pembelajaran, materi yang disampaikan akan lebih menarik, karena dalam video terdapat unsure-unsur audi dan visual yang membuat peserta didik menajdi lebih antusias dalam menyimak materi pelajaran. Selain itu, video pembelajaran yang menampilkan teks, gambar, video, suara dalam satu paket mampu mengakomodasi berbagai gaya belajar siswa ${ }^{35}$.

Perbedaan peningkatan motivasi dan hasil belajar siswa dalam pelajaran Front Office di Kelas XI Akomodasi Perhotelan SMKN 3 Garut dengan menggunakan video pembelajaran efektif nilai variabel motivasi di kelas kontrol sejumlah 57,07 sedangkan di kelas eksperimen menunjukkan angka yang cukup tinggi yaitu 60,34 dan terlihat perbedaan hasil belajar siswa di kelas kontrol pada saat pretest hanya mendapat rata-rata skor 39,83 dan posttest 51,33 sedangkan pada kelas eksperimen mendapat rata-rata skor 45,34 dan posttest 63,28.

Hal tersebut menunjukkan kesesuaian antara teori dan hasil penelitian yang menunjukkan adanya video pembelajaran sebagai salah satu media pembelajaran, bahkan

\footnotetext{
${ }^{33}$ Sukmadinata, N. S. 2007. Landasan Psikologi Proses Pembelajaran. Bandung: Rosdakarya. hlm. 23.

${ }^{34}$ Syam, I. 2015. Teori hasil belajar menurut para ahli. Tersedia: http://www.slideshare.net/ismdn/teorihasil-belajar-menurut-para-ahli diakses 10 Juni 2019 pukul 13.00.

${ }^{35}$ Purwanto, N. 2002. Administrasi Dan Supervisi Pendidikan. Bandung: PT. Remaja Rosdakarya. hlm. 46.
} 
multimedia pembelajaran yang memberikan dampak atau pengaruh yang positif terhadap peningkatan ketercapaian tujuan pembelajaran motivasi dan hasil belajar siswa ${ }^{36}$. Pengetahuan yang diperoleh siswa akan semakin abstrak apabila hanya disampaikan melalui bahasa verbal yang memungkinkan terjadinya verbalisme dalam belajar, artinya bahwa penggunaan media dalam pembelajaran agar pengalaman siswa dalam belajar lebih konkret, pesan yang disampaikan benar-benar mencapai tujuan yang ingin dicapai, dapat mendekatkan siswa dengan kondisi yang sebenarnya. Dengan demikian, maka dapat dikatakan bahwa media video pada dasarnya akan mendukung proses pembelajaran yang lebih utuh, siswa lebih aktif dan kreatif bagi siswa khususnya dalam memperoleh pengalaman dan perilaku sesuai dengan pengalaman masing-masing dalam domain kognitif. Menurut Edgar Dale memaparkan tentang Cone of Experirence (kerucut pengalaman), bahwa siswa akan mendapatkan pengalaman belajar yang lebih apabila mendapatkan pembelajaran dengan menggunakan multimedia (gabungan antara animasi, audio, video, dan teks) dibanding dengan pembelajaran metode biasa yang mengandalkan metode verbal dalam penyampaian materi ${ }^{37}$.

Kemampuan ingatan akan lebih tinggi pada siswa yang mendapatkan pembelajaran dengan bantuan media video dibandingkan dengan siswa yang hanya mendapatkan pembelajaran dengan metode biasa yang hanya mengandalkan teknik verbal atau ceramah. Dengan metode biasa, informasi mungkin bisa disimpan oleh otak, akan tetapi hanya sementara sehingga pada saat terjadi proses pemanggilan kembali informasi menjadi lebih lambat dan sulit. Sementara dengan media video, adanya gambar memicu atau merangsang otak untuk

\footnotetext{
${ }^{36}$ Rasyid, H \& Mansyur. 2008. Penilaian Hasil Belajar. Bandung: Wacana Prima. hlm. 36.

${ }^{37}$ Undang-Undang Nomor 20 Tahun 2003 tentang Sistem Pendidikan Nasional. LamanDepDikNas [online]. Tersedia: http//:www.depdiknas.go.id/uusisdiknas.htm. diakses 2 Juni 2019.
}

selalu ingat dan mudah apabila dilakukan pemanggilan informasi tersebut $t^{38}$.

Berkaitan dengan hasil penelitian dan analisis data yang berkaitan dengan rumusan masalah yang dirumuskan pada bab yang pertama menunjukkan adanya kesesuaian antara kajian teori yang dipaparkan pada bab kedua dengan hasil yang dapat di lapangan. Hal ini menunjukkan bahwa penerapan video dalam pembelajaran front office memberikan dampak positif terhadap perkembangan ketercapaian tujuan pembelajaran ${ }^{39}$. Manfaat dari penggunaan media ini, antara lain: (1) memperluas cakrawala sajian materi pembelajaran yang diberikan di dalam kelas, sehingga siswa akan memiki banyak pilihan sesuai kebutuhan dan karakteristik masing-masing. (2) siswa akan mendapatkan pengalaman belajar beragam selama proses pembelajaran. (3) memberikan pengalaman belajar yang kongkret dan langsung kepada siswa. (4) menyajikan sesuatu yang sulit diadakan, dikunjungi atau di lihat oleh siswa, seperti halnya proses tumbuh dan berkembangnya manusia yang memerlukan waktu lama dalam prosesnya. (5) memberikan informasi yang akurat dan terbaru. (6) menambah kemenarikan tampilan materi sehingga meningkatkan motivasi dan minat serta mengambil perhatian siswa untuk fokus mengikuti materi yang di sajikan. Sehingga diharapkan efektivitas belajar menjadi meningkat pula. (7) merangsang siswa untuk berfikir kritis. (8) meningkatkan efisiensi proses pembelajaran. (9) membantu memecahkan masalah-masalah dalam pendidikan ${ }^{40}$.

Berdasarkan ungkapan Asyhar di atas menunjukkan hal yang tepat bagi sebuah metode pembelajaran yang berperan dalam meningkatkan ketercapaian tujuan dalam

${ }^{38}$ Warsita, B. 2008. Teknologi Pembelajaran (landasan dan Aplikasnya). Jakarta: Rineka Cipta. hlm. 26.

${ }^{39}$ Arsyad, A. 2002. Media Pembelajaran. Jakarta: PT. Raja Grafindo Persada. hlm. 38.

${ }^{40}$ Hartono. 2010. SPSS 16.0 Analisis Data Statistik dan Penelitian Edisi Ke-2. Yogyakarta: Pustaka Pelajar. hlm. 28 . 
pembelajaran terutama dalam mata pelajaran front office yang merupakan mata pelajaran yang menitik beratkan kepada hal yang praktik yaitu bagaimana aplikasi dilapangan yang harus dilandasi oleh teori juga contoh yang baik agar dalam pelaksanaannya di dunia industri sesuai dengan SOP (Standar Operation Procedure) ${ }^{41}$.

Masing-masing lingkungan belajar memiliki orientasi dan kekhasan sendirisendiri. Lingkungan preskriptif menekankan bahwa prestasi belajar merupakan pencapaian dari tujuan-tujuan belajar yang ditetapkan secara eksternal. Interaksi belajar terjadi antara siswa dengan bahan-bahan belajar yang sudah tersedia dan belajar merupakan suatu kegiatan yang bersifat prosedural. Lingkungan belajar demokratis menekankan kontrol proaktif siswaatas proses belajarnya sendiri, yang mencakup penetapan tujuan belajarsendiri, kontrol siswa terhadap urutanurutan pembelajaran, hakekatpengalaman dan kedalaman materi belajar yang dicarinya. Sedangkan lingkungan belajar sibernetik menekankan saling ketergantungan antara sistem belajar dan siswa.

Untuk menerapkan media video pada lembaga pendidikan, khususnya di sekolahsekolah, tentunya ada standar minimal khusus yang harus dipenuhi paling tidak dari sisi sarana dan prasarana atau fasilitas. Komputer atau laptop adalah sarana yang wajib tersedia agar dapat menerapkan pembelajaran berbasis ini. Komputer atau laptop ini juga harus dilengkapi dengan program-program yang mendukung media video, agar bisa dioperasikan di komputer atau laptop tersebut. Kemudian yang juga penting adalah Sumber Daya Manusia, dalam hal ini guru yang akan menjadi fasilitator pembelajaran, juga harus menguasai programprogram komputer, yang berkaitan dengan penggunaan media video ${ }^{42}$.

Dalam mencapai tujuan pembelajaran banyak faktor yang mempengaruhi ketercapaian

${ }^{41}$ Munir. 2012. Multimedia (Konsep dan Aplikasi dalam Pendidikan). Bandung: Alfabeta. hlm. 23.

${ }^{42}$ Darmawan, D. 2011. Inovasi Pendidikan. Bandung: PT. Remaja Rosdakarya. hlm. 45. dari tujuan tersebut. Faktor-faktor yang mempengaruhi ini satu dengan yang lainnya saling berkaitan, sehingga apabila faktor yang satu terabaikan maka hasil belajar itu sendiri menjadi tidak optimal. Faktor yang berpengaruh terhadap ketercapaian belajar yaitu ${ }^{43}:$ 1) faktor guru, 2) faktor siswa, 3) faktor sarana prasarana, dan 4) faktor lingkungan. Dari keempat faktor tersebut, tentunya masing-masing mempengaruhi hal yang berbeda, akan tetapi secara keseluruhan semuanya merujuk pada ketercapaian tujuan pembelajaran, yang diukur dari hasil belajar yang diperoleh melalui evaluasi ${ }^{44}$.

Diharapkan video pembelajaran, dapat mencakup aspek-aspek yang memiliki peranan penting dalam membantu guru mejelaskan materi pelajaran yang disampaikan, sehingga guru dapat lebih kreatif dalam menyiapkan materi yang menarik sehingga meningkatkan motivasi siswa dalam mengikuti proses pembelajaran ${ }^{45}$. Inti dari karya ilmiah ini ingin menujukan keefektifan penggunaan video pembelajaran dalam menciptakan iklim pembelajaran yang lebih kondusif sehingga akan meningkatkan motivasi dan hasil belajar siswa dalam rangka meraih kualitas pembelajaran yang bersaing sehingga melahirkan sumber daya manusia yang kompeten baik di dalam negeri juga di cakupan internasional dalam menyongsong Indonesia sebagai negara yang siap "lepas landas" untuk menjadi salah satu negara adidaya.

\section{KESIMPULAN}

Berdasarkan hasil temuan penelitian, analisis data serta pembahasan pada bab sebelumnya maka disimpulkan beberapa temuan penelitian antara lain.

1. Penggunaan video pembelajaran efektif untuk dapat meningkatkan motivasi siswa dalam pembelajaran Front Office di Kelas XI Akomodasi Perhotelan SMKN 3 Garut.

\footnotetext{
${ }^{43}$ Arikunto, S. 1999. Dasar-Dasar Evaluasi Pendididkan. Jakarta: Bumi Aksara. hlm. 47.

${ }^{44}$ Bagyono. 2006. Dasar-Dasar Kantor Depan Hotel. Yogyakarta: CV. Andi Offset. hlm. 47.

${ }^{45}$ Aryani, N \& Haryanto, D. (2010). Pembelajaran Multimedia Sekolah. Jakarta: PT. Pustaka Raya. hlm. 64.
} 
2. Penggunaan video pembelajaran efektif untuk dapat meningkatkan hasil belajar siswa dalam pembelajaran Front Office di Kelas XI Akomodasi Perhotelan SMKN 3 Garut.

3. Penggunaan video pembelajaran efektif untuk dapat meningkatkan motivasi dan hasil belajar siswa dalam pembelajaran Front Office di Kelas XI Akomodasi Perhotelan SMKN 3 Garut.

\section{DAFTAR PUSTAKA}

Adriyanto, Prinsip Pendidikan Vokasi. Tersedia: http://1 ptk.blogspot. com/2011/11/prinsip-pendidikanvokasional-dari.html. diakses 12 Maret 2019 pukul 15.33, 2011

Arikunto, Suharsimi, Dasar-Dasar Evaluasi Pendididkan, (Jakarta: Bumi Aksara, 1999)

Arsyad, Media Pembelajaran, (Jakarta: PT. Raja Grafindo Persada, 2002)

Aryani, N \& Haryanto, D, Pembelajaran Multimedia Sekolah (Jakarta: PT. Pustaka Raya, 2007)

Bagyono, Dasar-Dasar Kantor Depan Hotel, (Yogyakarta: CV. Andi Offset, 2006)

Darmawan, Deni, Inovasi Pendidikan (Bandung: PT. Remaja Rosdakarya, 2011)

Jaenudin, Riswan, Pengaruh Penggunaan Media Video Terhadap Motivasi Dan Hasil Belajar Siswapada Mata Pelajaran Ilmu Pengetahuan Social Di Sekolah Menengah Pertama Negeri 2 Lais Musi Banyu Asin. Tersedia: http://www.distrodoc. com/279312-pengaruh -penggunaan -media -video -terhadap -motivasi -dan hasil -belajar. Diakses 3 November 2019 pukul 00.30, 2015

Listianing, Hotel Front Office. Tersedia: http:// jenglis.blog.com/hotel-front-office/, (Diakses 25 Juni 2019 pukul 15.00, 2015)

Munir, Multimedia (Konsep dan Aplikasi dalam Pendidikan), (Bandung: Alfabeta, 2012)

Purwanto, N, Administrasi Dan Supervisi Pendidikan, (Bandung: PT. Remaja Rosdakarya, 2002)
Rasyid, H \& Mansyur, Penilaian Hasil Belajar, (Bandung: Wacana Prima, 2008)

Saadah, A. R, Penggunaan CD Interaktif Model Tutorial Untuk Meningkatkan Motivasi Dan Prestasi Belajar Ilmu Pengetahuan Social Siswa Di Kelas V Sekolah Dasar Negeri Haurpanggung III Kecamatan Tarogong Kidul Kabupaten Garut, (Garut: Tidak diperjualbelikan, 2014).

Sanjaya, Wina, Perencanaan dan Desain sistem Pembelajaran, (Jakarta: Kencana Prenada Media Group, 2008)

Sardiman, Interaksi dan Motivasi Belajar Mengajar, (Jakarta: PT Raja Grafindo Persada, 2010)

Slameto, Belajar dan Faktor-faktor yang mempengaruhinya, (Jakarta: Rineka Cipta, 2010)

Smaldino, S. E, Instructional technology and Media For learning, (Ohio: Pearson Merril prentice Hall, 2008)

Sudijono, Anas, Pengantar Evaluasi Pendidikan, (Jakarta: Raja Grafindo, 2009)

Sudjana, Nana, Dasar-Dasar Proses Belajar Mengajar, (Bandung: Sinar Baru Algesindo, 2009)

Sugiarto, Endar, Hotel front Office Administration (Administrasi Kantor Depan Hotel), (Jakarta: Gramedia Pusaka Utama, 2003)

Sugiyono, Statistik Nonparametris untuk penelitian, (Bandung: Alfabeta, 2009)

Sukardi, Metodologi Penelitian Pendidikan, (Jakarta: Bumi Aksara, 2010)

Sukmadinata, N S, Landasan Psikologi Proses Pembelajaran, (Bandung: Rosdakarya, 2007)

Sulastiyono, Agus, Manajemen Penyelenggaraan Hotel, (Bandung: Alfabeta, 2011)

Suminarsih, Inar, Pengaruh penggunaan media video pembelajaran terhadap peningkatan motivasi belajar dan keterampilan berbicara, (Garut: Tidak diperjualbelikan, 2013)

Sundayana, Rostina, Statistika Penelitian Pendidikan, (Garut: STKIP Press, 2011) 
Surya, M, Psikologi Pembelajaran dan Pengajaran, (Bandung: Pusaka Bani Quraisy, 2004)

Sutanto, Menerima dan memproses Reservasi, (Bandung: Alfabeta, 2011)

Suwithi, Ni Wayan, Pengantar Akomodasi Perhotelan Jilid 1, (Jakarta: Tidak diperjualbelikan, 2011)

Syah, Muhibbin, Psikologi Pendidikan dengan Pendekatan Baru, (Bandung: PT. Remaja Rosdakarya, 2001)

Syam, Islamudin, Teori hasil belajar menurut para ahli. Tersedia: http://www. slideshare.net/ismdn/teori-hasil-belajarmenurut-para-ahli diakses 10 Juni 2019 pukul 13.00, 2015

Undang-Undang Nomor 20 Tahun 2003 tentang Sistem Pendidikan Nasional. LamanDepDikNas [online]. Tersedia: http//:www.depdiknas.go.id/uusisdiknas. htm. diakses 2 Juni 2019.

Uno, Hamzah, Indikator Motivasi Belajar. Tersedia: http://pendidikanekonomi. com/2013/08/jenis-fungsi-dan-indikatormotivasi.html. Diakses: 2 Oktober 2019

Usman, Uzer, Menjadi Guru Profesional, (Bandung: PT Remaja Rosdakarya, 199) Warsita, B, Teknologi Pembelajaran (landasan dan Aplikasnya), (Jakarta: Rineka Cipta, 2008)

Wijaya, C \& Rusyan, T. A, Kemampuan Dasar Guru Dalam Mengajar, (Bandung: PT Remaja Rosdakarya, 1991)

Witte, James, P, Why The Tail The Dogs: The Pernicious Influence Of ProductOriented Discourse On The Provision Of Educational Technology Suport, (Journal of instructional Technology. 27, 203-215, 2007) 